\title{
Prevalence of small opacities in chest radiographs of nickel sinter plant workers
}

\author{
D C F Muir, J Julian, N Jadon, R Roberts, J Roos, J Chan, W Maehle, W K C Morgan
}

\begin{abstract}
Radiographs from 745 nickel sinter plant workers were taken and classified by five readers using the International Labour Office (1980) protocol. Each reader worked independently and the films were randomly mixed with films from a non-dust exposed office population and also with films from subjects known to have silicosis or asbestosis. The prevalence of small irregular opacities was selected as the outcome of interest. In the sinter workers this was within the range identified in cigarette smokers or in workers exposed to dusts of low fibrogenicity. Only minimal evidence of small round opacities was noted. There was no evidence from the chest radiographs that exposures to high concentrations of dusts containing compounds of nickel caused an inflammatory or fibrogenic response in the lungs of the exposed population.
\end{abstract}

(British Journal of Industrial Medicine 1993;50:428-431)

Nickel refinery workers in certain industrial processes are known to have been at increased risk of developing cancer of the lung or nose. ${ }^{1}$ Compounds of nickel thought to be responsible include the subsulphide, oxide, and sulphate. There is no evidence to associate metallic nickel with increased risks of cancer of the nose or lung; nor is there evidence that compounds of nickel are associated with cancers at other sites. ${ }^{2}$

Nickel is also known to cause contact dermatitis and, rarely, asthma. ${ }^{3}$ Although experimental work with animals has suggested that other effects such as

McMaster University, 1200 Main Street West, Hamilton, Ontario, Canada L8N $3 Z 5$

D C F Muir, J Julian, N Jadon, R Roberts

Occupational Health Branch, Medical Service Chest

Clinic, Ontario Ministry of Labour, 400 University

Avenue, Toronto, Ontario, Canada M7A 1 T7

J Roos, J Chan, W Maehle

University of Western Ontario, University Hospital,

339 Windermere Road, PO Box 5339, Station " $A$ " London, Ontario, Canada N6A 5A5

W K C Morgan inflammatory change in the lung can occur, ${ }^{45}$ there is no documented evidence of this in human populations, nor of increased mortality from non-malignant respiratory disease. A search for such evidence is important as it is essential to ensure that workers and the general population are protected from possible harm caused by the inhalation of nickel or of its compounds.

Our study was designed to investigate whether the inhalation of nickel subsulphide and nickel oxide is associated with fibrosis in the lung. Radiological evidence was selected as the outcome of importance. The sinter plant closed many years ago. Pulmonary function tests were not available at the time of employment in the sinter plant and it was thought unlikely that useful information could be obtained from current measurements even if these were available.

The sinter plant workers at Copper Cliff, Sudbury, Ontario, represent a special group. They were exposed to high concentrations of airborne dusts containing concentrations of nickel as high as 100 $\mathrm{mg} / \mathrm{m}^{3}$ and it was in this group that the epidemic of cancer of the lung and nose was found. ${ }^{2}$ If inhaled nickel compounds are capable of causing pulmonary fibrosis, it would have appeared in these sinter plant workers.

\section{Methods}

The study population consisted of workers who had been employed by the International Nickel Company in the sinter plant at Copper Cliff, Sudbury. The sinter plant operated between April 1948 and February 1963. When it became known that these workers were at risk of developing cancer of the respiratory tract a voluntary medical surveillance programme was started in 1973. The programme consisted of annual cytological tests of sputum for malignant cells and a full sized radiograph of the chest. The radiographs of workers who are still participating in the scheme were easily located and were available for study. Some workers originally in the scheme were no longer participating for reasons including retirement, change of employment, or death. Some workers, originally employed in the 
Table 1 Age distribution (\%) of sinter plant workers by duration of exposure to sinter

\begin{tabular}{|c|c|c|c|c|}
\hline \multirow[b]{2}{*}{$\begin{array}{l}\text { Duration of } \\
\text { exposure }\end{array}$} & \multicolumn{4}{|c|}{ Age (y) at time of radiograph } \\
\hline & $\begin{array}{l}20-34 \\
\text { No }(\%)\end{array}$ & $\begin{array}{l}35-49 \\
\text { No }(\%)\end{array}$ & $\begin{array}{l}50-64 \\
\text { No }(\%)\end{array}$ & $\begin{array}{l}\geqslant 65 \\
\text { No }(\%)\end{array}$ \\
\hline $\begin{array}{l}<5 \text { years } \\
\geqslant 5 \text { years }\end{array}$ & $\begin{aligned} & 49(8 \cdot 2) \\
& 0(0.0)\end{aligned}$ & $\begin{array}{rr}98 & (16.4) \\
7 & (4.7)\end{array}$ & $\begin{array}{r}358(60 \cdot 1) \\
78(52 \cdot 3)\end{array}$ & $\begin{array}{l}91(15 \cdot 3) \\
64(43 \cdot 0)\end{array}$ \\
\hline
\end{tabular}

sinter plant, did not join the surveillance scheme but became miners and had chest $x$ ray films in connection with that employment. Considerable efforts were made to identify all these subgroups and to locate the radiographs. Medical records at the company and of the miners' radiographic surveillance centre were searched. The final study population consisted of those men who were known to have been employed in the sinter plant and who subsequently had a chest radiograph for any of the reasons already noted $(n=745)$. It was not possible to obtain more recent films for men who left the company or the mining industry.

The two most recent films from each worker were classified by five readers (DCFM, JR, JC, WM, and WKCM) with the International Labour Office (ILO) 1980 protocol. Each reader classified the films independently. The origin and identity of each film was concealed by black masking tape. The films were presented to the readers in random order and were randomly mixed with films from non-dust exposed subjects that were similarly masked. These films were of civil servants with a similar age range to that of the study population and were taken for routine purposes. The films were not necessarily normal but there was no documented exposure to dust. Any abnormalities represent the general level of abnormality in an office population. Finally films from subjects known to have asbestosis, silicosis, or other respiratory disease were similarly masked and were randomised with the study films. These control films were included to ensure that the readers were unaware of the underlying prevalence of abnormality in the study films and were excluded from the subsequent analysis.

The readers had all read large batches of films and were familiar with the use of the ILO (1980) protocol. Two films were selected, where available, from each sinter plant worker. This was to allow for poor quality films that could not be classified.

\section{Results}

Tables 1-5 show the results. These are in the form of prevalence analyses. The prevalence of small opacities in the study films are shown for each reader separately.

Tables 1 and 2 show the age distribution of the subjects. The age refers to the age of an individual at the time when the radiograph was taken. Table 2 shows that most of the radiographs were taken many years after the year of first exposure.

Tables 3 and 4 show the overall distribution of small opacities, both round and irregular. There was no appreciable disease in the study population. The number of cases showing round opacities $\geqslant 1 / 0$ was too small for detailed analysis and attention was focused on irregular opacities. Table 5 shows the percentage of films with irregular opacities.

\section{Discussion}

The purpose of this study was to find whether heavy exposure to airborne dust in the sinter plant operation is associated with radiological evidence of a fibrogenic reaction. The appearance of small opacities was identified as the relevant measure of health outcome. These opacities are of two types-small round opacities are characteristic of the slow fibrosis caused by accumulations of dust containing free silica. They are most often seen in the apices of the lungs during the early stages of the disease and their presence is the hallmark of silicosis. The second type of opacity consists of irregular linear shadows and these are found in a number of diseases. Fibrosis due to asbestosis is characterised by irregular opacities in the base of the lungs. ${ }^{6}$ Other inflammatory disorders that may cause small irregular opacities include sarcoidosis, idiopathic fibrosing alveolitis, allergic alveolitis, and various disorders of connective tissue such as rheumatoid arthritis. Small irregular radiographic opacities are also a common finding in the normal population with increasing age and especially so in the case of cigarette smokers. ${ }^{7}$ This association has been the focus of much research because of the problem of identifying the cause of such opacities

Table 2 Distribution of time intervals $(y)$ between first exposure and year of radiograph for sinter plant workers

\begin{tabular}{llllllll}
\hline & \multicolumn{1}{l}{ Time since first exposure $(y)$} \\
\cline { 2 - 8 } Duration of exposure & $0-9 \mathrm{No}(\%)$ & $10-19 \mathrm{No}(\%)$ & $20-29 \mathrm{No}(\%)$ & $30-39 \mathrm{No}(\%)$ & $40-44 \mathrm{No}(\%)$ \\
\hline$<5$ years & $42(7 \cdot 1)$ & $44(7 \cdot 4)$ & $133(22 \cdot 3)$ & 240 & $(40 \cdot 3)$ & $137(23 \cdot 0)$ \\
$\geqslant 5$ years & $0(0 \cdot 0)$ & $3(2 \cdot 0)$ & $41(27 \cdot 5)$ & $59(39 \cdot 6)$ & $46(30 \cdot 9)$ \\
\hline
\end{tabular}


Table 3 Classification of films (round opacities only) for sinter plant workers by duration of exposure (five readers)

\begin{tabular}{|c|c|c|c|c|c|c|c|c|c|c|}
\hline \multirow{3}{*}{$\begin{array}{l}\text { ILO } \\
\text { profusion } \\
\text { score }\end{array}$} & \multirow{2}{*}{\multicolumn{2}{|c|}{$\frac{\text { Reader } 1}{\text { Exposure (y) }}$}} & \multirow{2}{*}{\multicolumn{2}{|c|}{$\frac{\text { Reader } 2}{\text { Exposure (y) }}$}} & \multirow{2}{*}{\multicolumn{2}{|c|}{$\frac{\text { Reader } 3}{\text { Exposure }(y)}$}} & \multirow{2}{*}{\multicolumn{2}{|c|}{$\frac{\text { Reader } 4}{\text { Exposure (y) }}$}} & \multirow{2}{*}{\multicolumn{2}{|c|}{$\frac{\text { Reader } 5}{\text { Exposure }(y)}$}} \\
\hline & & & & & & & & & & \\
\hline & $<5$ & $\geqslant 5$ & $<5$ & $\geqslant 5$ & $<5$ & $\geqslant 5$ & $<5$ & $\geqslant 5$ & $<5$ & $\geqslant 5$ \\
\hline $0-$ & $=$ & 二 & - & - & - & - & - & - & - & - \\
\hline $\begin{array}{l:l}0 & 0 \\
0 & 1\end{array}$ & $\overline{1}$ & 二 & $\overline{3}$ & $\overline{1}$ & 二 & 二 & $\overline{1}$ & $\overline{-}$ & $\overline{7}$ & $\overline{7}$ \\
\hline 10 & 1 & - & 1 & - & 2 & - & - & - & 1 & 1 \\
\hline 11 & - & - & $i$ & 1 & 2 & - & - & - & - & - \\
\hline $1 / 2$ & - & - & - & - & - & 1 & - & - & - & - \\
\hline $2 / 1$ & - & - & - & - & - & - & - & 1 & - & - \\
\hline $2 / 2$ & - & - & - & - & - & 1 & - & - & - & 1 \\
\hline
\end{tabular}

when found in any worker who may have had some exposure to asbestos or other fibrogenic dust of occupational origin. ${ }^{89}$ The clinical significance, if any, of such opacities in workers exposed to high dust concentrations has also been a matter of debate and research. ${ }^{10}$ It is generally agreed that the prevalence of irregular opacities in a non-industrial population is related to smoking habits and to the age of the population. The prevalence of small opacities reported in a given survey depends also on the characteristics of those reading the radiographs. Disagreement between readers is documented to the extent that a threefold difference between experienced readers is by no means unknown.

In the present study, control films from a population not exposed to dust and from workers known to have asbestosis or silicosis were randomised with the index film. The purpose of this manoeuvre was to ensure that the readers were not aware of the underlying prevalence of abnormality in the radiographs of the sinter plant workers. Radiographic classification of films for pneumoconiosis is subjective and there is no absolute or external "gold standard". For this reason bias can only be avoided with certainty if the films in a particular study or legal case are fully randomised with an adequate number of positive and negative control films. The results for each reader are presented separately. Variability between readers is such that it cannot be assumed that films assigned to an abnormal category by one reader would also be identified as abnormal by any of the other readers. The best overall estimate of the underlying prevalence of abnormality may thus be the mean or median of the five readers. The basic data are provided, however, so that others may average the results if desired. An alternative approach is to average the readings on each film. Where the prevalence of abnormality is low, as in the present investigation, the resulting values are too small to be useful. The most recent film from each worker was selected for study to ensure the maximum latency since last exposure. This was to detect any inflammatory or fibrotic changes that might have developed after the worker left exposure, as has been reported in the case of asbestos workers. ${ }^{11}$ Resolution of small round opacities after removal from exposure has been reported in welders in whom it seemed likely that the opacities represented accumulations of radio-opaque dust containing iron, rather than a fibrotic or inflammatory response to dust. ${ }^{12}$ As far as is known, opacities due to a fibrotic process do not resolve after removal of the subject from exposure. For this

Table 4 Classification of films (irregular opacities only) for sinter plant workers by duration of exposure (five readers)

\begin{tabular}{|c|c|c|c|c|c|c|c|c|c|c|}
\hline \multirow{3}{*}{$\begin{array}{l}\text { ILO } \\
\text { profusion } \\
\text { score }\end{array}$} & \multirow{2}{*}{\multicolumn{2}{|c|}{$\frac{\text { Reader } 1}{\text { Exposure }(y)}$}} & \multirow{2}{*}{\multicolumn{2}{|c|}{$\frac{\text { Reader } 2}{\text { Exposure }(y)}$}} & \multirow{2}{*}{\multicolumn{2}{|c|}{$\frac{\text { Reader } 3}{\text { Exposure }(y)}$}} & \multirow{2}{*}{\multicolumn{2}{|c|}{$\frac{\text { Reader } 4}{\text { Exposure }(y)}$}} & \multirow{2}{*}{\multicolumn{2}{|c|}{$\begin{array}{l}\text { Reader } 5 \\
\text { Exposure (y) }\end{array}$}} \\
\hline & & & & & & & & & & \\
\hline & $<5$ & $\geqslant 5$ & $<5$ & $\geqslant 5$ & $<5$ & $\geqslant 5$ & $<5$ & $\geqslant 5$ & $<5$ & $\geqslant 5$ \\
\hline $0 /-$ & - & Z & - & 二 & - & 二 & 二 & - & - & I \\
\hline $\begin{array}{l}0 / 0 \\
0 / 1\end{array}$ & 28 & 13 & 22 & 7 & 21 & 6 & 35 & $\overline{8}$ & $\overline{12}$ & $\overline{7}$ \\
\hline $1 / 0$ & 2 & 5 & 2 & 2 & 24 & 13 & 6 & 8 & 2 & 2 \\
\hline $1 / 1$ & 4 & 4 & - & 1 & 2 & 6 & 3 & 5 & 2 & $\overline{6}$ \\
\hline $1 / 2$ & - & 2 & - & - & - & 3 & - & 1 & - & 2 \\
\hline 21 & - & 1 & 1 & 1 & - & 1 & - & - & - & 1 \\
\hline $2 / 2$ & - & 1 & 1 & - & 2 & - & - & - & 2 & - \\
\hline $2 / 3$ & 1 & - & - & - & - & - & - & - & - & - \\
\hline 32 & 1 & - & - & - & - & - & - & - & - & - \\
\hline 33 & - & - & 1 & - & - & - & - & - & - & - \\
\hline
\end{tabular}


Table 5 The percentage of films classified as $\geqslant 0 / 1, \geqslant 1 / 0$, and $\geqslant 1 / 1$ (irregular opacities only) for sinter plant workers with more than 5 years of exposure

\begin{tabular}{lccccc}
\hline $\begin{array}{l}\text { ILO } \\
\text { profusion } \\
\text { score }\end{array}$ & $\begin{array}{l}\text { Reader } \\
1\end{array}$ & $\begin{array}{l}\text { Reader } \\
2\end{array}$ & $\begin{array}{l}\text { Reader } \\
3\end{array}$ & \multicolumn{1}{c}{$\begin{array}{l}\text { Reader } \\
4\end{array}$} & \multicolumn{1}{c}{$\begin{array}{l}\text { Reader } \\
5\end{array}$} \\
\hline$\geqslant 0 / 1$ & $17 \cdot 4$ & $7 \cdot 4$ & $19 \cdot 5$ & $14 \cdot 8$ & $\begin{array}{r}12 \cdot 1 \\
\geqslant 1 / 0\end{array}$ \\
$\geqslant 1 / 1$ & $5 \cdot 4$ & $2 \cdot 7$ & $15 \cdot 4$ & $9 \cdot 4$ & $\begin{array}{r}7 \cdot 4 \\
\text { No }\end{array}$ \\
\hline
\end{tabular}

reason, the study design maximised the possibility of detecting abnormalities if exposure to nickel dust was a significant aetiological factor.

In this study the prevalence of small opacities (round and irregular combined) in the sinter plant workers was low. Because there was a long latent period and a significant number of workers exposed to remarkably high concentrations of dust containing nickel this provides strong evidence that the inhaled dust was not of the type causing pneumoconiosis. The prevalence of irregular opacities in the sinter plant workers was similar to that in published studies of smoking populations and those exposed to dusts of low fibrogenic potential. ${ }^{78}$ This is evidence against the hypothesis that dusts containing nickel can cause a significant fibrotic response in human subjects and is in accord with mortality studies that have not shown evidence of an increase in the risk of death as a result of non-malignant respiratory disease. ${ }^{1}$
We are grateful to the Nickel Producers Environmental Research Association for financial support for this study.

1 Roberts RS, Julian JA, Muir DCF, Shannon HS. A study of mortality in workers engaged in the mining, smelting, and refining of nickel. Toxicol Ind Health 1989;5:957-93.

2 Report of the international committee on nickel carcinogenesis in man. Scand J Work Environ Health 1990;16:1-81.

3 McConnell LH, Fink JN, Schlueter DP, Schmidt MC. Asthma caused by nickel sensitivity. Ann Intern Med 1973;78:888-90.

4 Benson JM, Burt DG, Cheng YS, et al. Biochemical responses of rat and mouse lung to inhaled nickel compounds. Toxicology 1989;57:255-66.

5 Dunnick JK, Elwell MR, Benson JM, et al. Lung toxicity after 13-week inhalation exposure to nickel oxide, nickel subsulfide, or nickel sulfate hexahydrate in $\mathrm{F} 344 / \mathrm{N}$ rats and $\mathrm{B} 6 \mathrm{C} 3 \mathrm{~F} 1$ mice. Fundam Appl Toxicol 1989;12:584-94.

6 Berry G, Gilson JC, Holmes S, Lewinsohn HC, Roach SA. Asbestos: a study of dose-response relationships in an asbestos textile factory. $\mathrm{Br} J$ Ind Med 1979;36:98-112.

7 Weiss $\mathrm{W}$. Cigarette smoking and small irregular opacities. $\mathrm{Br} \mathrm{J}$ Ind Med 1991;48:841-4.

8 Amandus HE, Lapp NL, Jacobson G, Reger RB. Significance of small irregular opacities in radiographs of coal miners in the USA. Br J Ind Med 1974;33:13-7.

9 Weiss W. Cigarette smoke, asbestos and small irregular opacities. Am Rev Respir Dis 1984;130:293-301.

10 Dick AJ, Morgan WKC, Muir DCF, Reger RB, Sargent N. The significance of irregular opacities in the chest radiograph. Chest 1992;102:251-60.

11 Becklake MR, Liddell FDK, Manfreda J, McDonald JC. Radiological changes after withdrawal from asbestos exposure. Br J Ind Med 1979;36:23-8.

12 Marek K, Kujawaska A. Evolution of functional respiratory disorders in different types of pneumoconiosis. Bulletin de Physio-pathologie Respiratoire 1975;11:597-610.

Accepted 6 July 1992 